\title{
Inundation Calculation of the Coastal Narrow Plain Strip Impacted by Upstream Reservoir Flood Discharge in Rainy and Extreme Flood Conditions
}

\author{
Nguyen Ngoc Nam ${ }^{1}$, Le Van Nghi and Bui Thi Ngan \\ Key Laboratory of Hydraulics, River and Coastal Engineering, 1/165, Chua Boc Street, Hanoi, Vietnam
}

\begin{abstract}
In the context of current climate change, an abnormality of flooding is a common form of disaster in Vietnam. Hanh Stream reservoir has occurred great flood in 1986, 2010. In the future, the risk of flooding is possible to happen again. In view of management of the risk of natural disasters: large flooding situation downstream is one of the most dangerous risks for the reservoir. Due to downstream of Hanh Stream reservoir is a narrow coastal plains, quick infrastructure development, especially interwoven road and railway systems, so that flood drainage ability will be affected greatly. The consciousness of risks that may be occurred in the future in order to propose preventive measures and proactive response to minimize damages always is the requirement for all projects. The hydrodynamic calculation, flooding maps, emergency plan to prevent flooding downstream of Hanh Stream reservoir is also needed. The article is raised the issue of requirements to calculate coastal narrow delta strip flooding in the Central of Vietnam when impacted by the upstream reservoir of flood discharge in terms of extreme heavy rain and flooding and presented computational methods of Mike software package for case flooded plain of Cam Ranh Bay in downstream reservoirs of Hanh Stream, Khanh Hoa Province, Vietnam.
\end{abstract}

Key words: Reservoirs, Hanh Stream, maps, inundation, narrow plain, narrow delta, coastal, hydrodynamic calculation, flood, flooding.

\section{Introduction}

\subsection{Research Rationale}

Currently, the world is faced with the climate change problem, including flooding phenomena beyond the normal rules. Vietnam is located in the strongly fragmented climate region, time of rainy season is changed slowly from north to south, usually from July to November, December with biggest operating frequency in the country of storms so the central is the local that head of the country about the frequency of rain, extreme large floods with devastating force.

On the other hand, with the natural terrain conditions, most river basins are in the steep slopes

Corresponding author: Nguyen Ngoc Nam, Ph.D., major researcher, research fields: numerical and physical modelling of river and coastal processes including waves, tides, sediment transport. eastern of Truong Son mountains. The narrow coastal delta strips have formed due to the divide by mountains jutting across out to sea. Besides, the river network in central is quite dense with over 740 rivers over $10 \mathrm{~km}$ in length [1]. Most river basins are small, short and very steep. There are many low-lying deltas and the estuary has always been volatile by sedimentation. These are the natural factors to increase the risk of flooding.

In recent years, with the goal of social and economic development, agricultural development, many reservoirs have been built for power generation and water supply for agriculture in large river basins in the Central of Vietnam. These reservoirs have an important contribution to the power supply for the central region in particular and the socio-economic development in general. However, the watershed forests are heavily damaged. Due to the fact that most 
of the reservoirs and hydropowers are built in upstream, therefore the ability to regulate the flow is reduced significantly. On the other hand, floods in the Central River basin have different characteristics from both South and North. They are faster and larger intensity (e.g. the abnormal floods in Nghe An, Ha Tinh, Quang Binh in October 2010. There was a phenomenon of superimposed flood, the front flood was not drained down but the next floods had stomped on. In addition, the intensity of the next flood was huge; 1 day rainfall at Chu Le -Huong Khe - Ha Tinh measured as $800 \mathrm{~mm}$; total rainfall of 5 days up to $1,300 \div 1,500 \mathrm{~mm}$ ) and the total amount of water is put into the river valley caused terror flooding in the coastal narrow plain $[2,3]$.

Besides that, the fast variation of infrastructure especially roads system with the development of other infrastructure such as ground level for building urban zones, residential has changed very large to the flood cells, as well as increased the level of exposed threats of downstream. This leads to damage or to loss of people, livelihoods, infrastructure, economic assets society.

In the current period, the computational research of inundation of narrow plain trip in central coast when suffered by the impact of the flood discharge of the upstream reservoir in terms of heavy rainfall, extremist floods in order to have a basis scientific to propose response solutions is extremely necessary. Therefore, the article is focused on this area and the downstream reservoirs of Hanh Stream (narrow strip of coastal plain Cam Ranh Bay area), in Khanh Hoa province is selected as a case study.

The methodology and flooding calculated results of coastal narrow plains of downstream reservoirs of Hanh Stream, Khanh Hoa province are described in this study. In which, tools such as rainfall-runoff model MIKE NAM, hydraulic model MIKE 11, overflow dumps model MIKE 21 and inundation model MIKE FLOOD are used to analyze and calculate the Hanh Stream basin.

\subsection{Research Objectives}

In the work: "Prepare plans for prevention from floods in downstream areas of Hanh Stream reservoir", Khanh Hoa province, hydraulic calculations will be the basis for an assessment of the flooding situation of Hanh Stream and inundation levels of downstream areas according to the flood control planning schemes to limit the flooding harmful effects in downstream Hanh Stream. Thereby, there is a scientific basis for:

- Define or anticipate the dangerous, urgent situation in the case of flood discharge and the occurrence of the incident. Identify flash floods line and flooding scope with the aforementioned dangerous situation;

- Construction of flood maps in order to support for the management and risk reduction.

The content of this paper, mainly refers to the methods and results of hydraulic calculations and flooding map of downstream of Hanh Stream reservoir.

\subsection{Research Scope}

Downstream of Hanh Stream reservoir is a narrow strip coastal plain of the Cam Ranh city and Cam Lam district. The whole downstream area is surrounded both sides (north and south) by the jutting out mountains to sea. The east is blocked by Cam Ranh Bay. The west and northwest upper is shielded by Hanh Stream reservoir and Ta Ruc reservoir (under construction). The Hanh Stream reservoir downstream region is located on lifeline roads of Khanh Hoa connecting the Nha Trang with other local in the country and the abroad. So that the speed development of urban infrastructure and the population is very fast. This is an urban area that inherited the entire developed infrastructure covering airline, waterways, road and rail.

- Airways: Cam Ranh city has Cam Ranh International Airport, an important traffic hub of Khanh Hoa province in particular and the South Central region in general. It is the 4 th largest airport of 

Reservoir Flood Discharge in Rainy and Extreme Flood Conditions

Vietnam based on the number of clearance passengers.

- Railways: Cam Ranh is situated on the North-South railway line, which is very convenient for connection with the rest of Vietnam. However, there is only a small station, namely Nga Ba station, in the city. This old station, abandoned for over 20 years, had just restored to receive guests since 2007. The Unified Ship had come through Cam Ranh but not refilled Nga Ba station for taking and discharging passengers. At currently, the station only pickups the passengers of trains SN1-2, SN3-4 on Saigon-Nha Trang voyages. In the future, the Nga Ba station will be upgraded to accommodate for unified railways.

- Waterways: there are two large ports in the city:

(1) Cam Ranh Port (formerly the Ba Ngoi port), stationed in Cam Linh Ward (Ba Ngoi former area), directly under Nha Trang port authority. This is an important international commercial port in Cam Ranh Bay, the convergence of the very favorable natural conditions for the development of port services such as water depth, sheltered wind, large area, that located near the international maritime and Cam Ranh Airport, $1.5 \mathrm{~km}$ from National Highway $1 \mathrm{~A}$ and $3 \mathrm{~km}$ from North-South railway line. The port had an important clue of sea transport for South Khanh Hoa and other close provinces for long time ago;

(2) Cam Ranh military port is a major military port located in the South, Cam Ranh Peninsula, where it is headquartered Command of D Navy area was a complex important base of the US in Vietnam War.

- Roads: Cam Ranh is far Nha Trang about $60 \mathrm{~km}$ in the south, is far Phan Rang about $40 \mathrm{~km}$ in the north. Cam Ranh also includes a very convenient road transport system: Highway 1A passing over $40 \mathrm{~km}$ through the city, provincial highway 9 linking the city center with the To Hap town, Khanh Son district, Nguyen Tat Thanh avenue connecting the Cam Ranh city with Cam Ranh Airport and Nha Trang. Cam Ranh Bus services most of the intra-provincial and inter-provincial cities.

There were time and place, the quick and uneven development of transport systems was beyond of the management and planning capacity of local authorities. On the other hand, the system of crisscrossed roads will be huge obstacle in the drainage of flood when there is problem in the upstream or in case of heavy rain and flooding.

Besides that, upstream of the Cam Ranh Bay delta is Hanh Stream Reservoir, which belongs to Irrigation Management and Operation Company of Nam Khanh Hoa that began construction in early 1985 with the irrigating mission for 700 hectares of rice and crops, of Cam Phuoc commune, Cam Ranh Town, Khanh Hoa province. By the end of Sep 1986, the reservoir headworks (including earth dams, flood overflow and intake sluice) basically finished. The dam was incidentally broken by the flood of beginning of Dec 1986. In 1989 entire headworks were remedied. Since then, it has been operating safety for nearly 20 years. In 2012, reservoir was re-constructed to upgrade the headworks items. Besides the aim of improving the capacity of the irrigation for 700 hectares of land for agricultural production, aquaculture in Cam Lam District and the city of Cam Ranh, HanhStream also provides drinking water for 755 people, who are settled in downstream.

However, due to the dam is blocking Hanh Stream and partly lying of river basin where Ta Ruc dam is being constructed is an area where the terrain is narrow, steep and concentrate flow rate in downstream is very fast. Downstream area of dam is influenced by the tides and very easily generated inundation in cased of flooding. River system here, naturally of the general characteristics of the Central River is short and steep, quickly concentrated flow rate. At the estuary, flood drainage capacity will be affected by tidal regim.

Hydraulic calculation problem is solved on the basis of one-dimensional model (MIKE 11) and flooding problems are connected with two-dimensional model. 
The construction of flood maps of narrow coastal plains is limited in the scope of downstream of Hanh

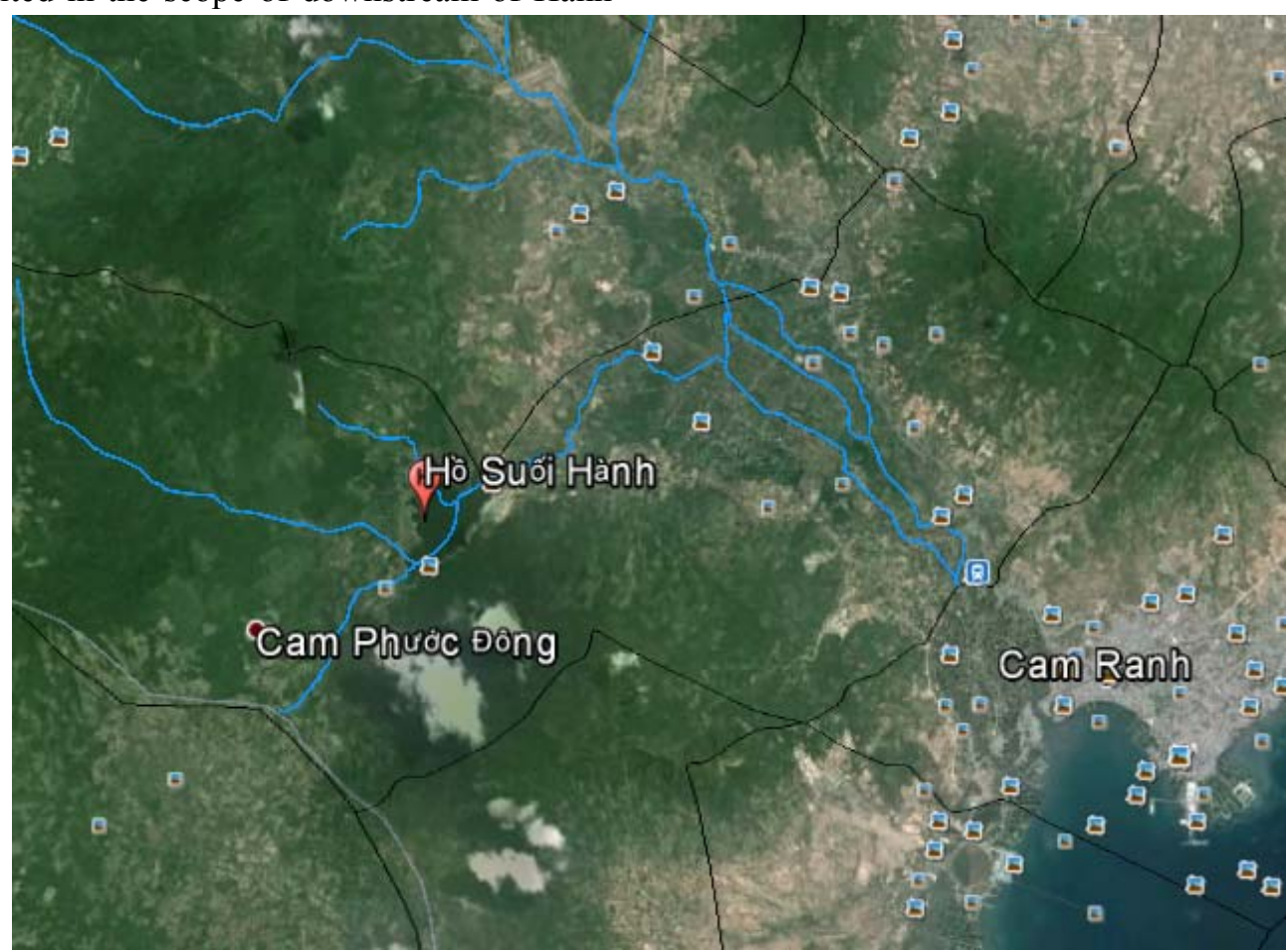

Fig. 1 Scope of flow simulation on the river system.

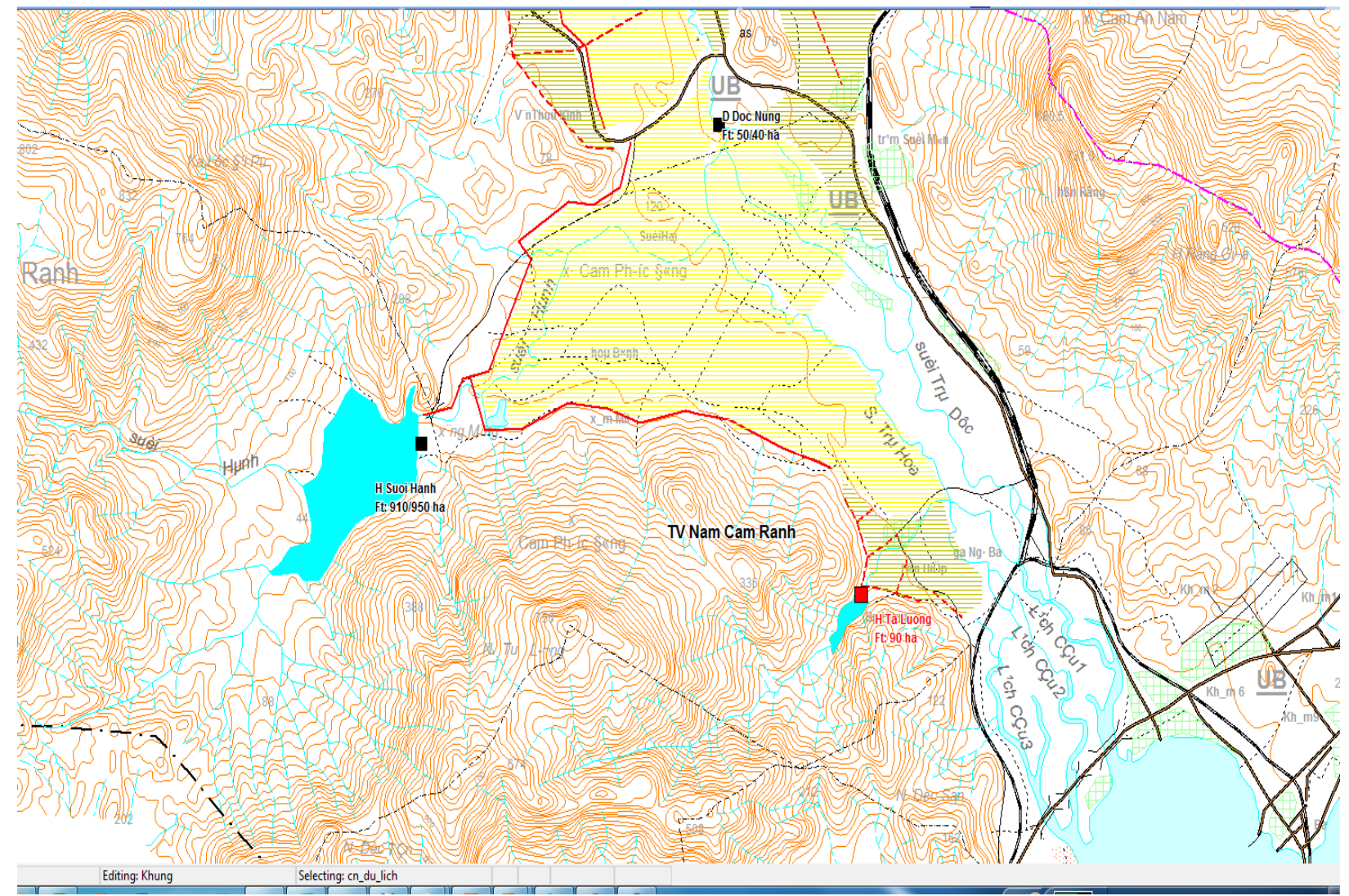


Fig. 2 Downstream of Hanh Stream reservoir.

Stream water reservoirs in the locality of Cam Ranh City and Cam Lam district, Khanh Hoa province.

\section{Methodology}

The problem of hydraulic calculations and mapping of flooding the water reservoir downstream is a complex issue, which requires more manpower on various subjects such as hydraulic structures, hydraulics, hydrology, topographical survey, geological, economic, social, etc.:

- Collect, examine and supplement the basic data in the project area; collect socio-economic data, social and data systems of irrigation, infrastructure, population distribution;

- Evolutions flooding, loss of major floods, especially in dam break in Dec. 1986;

- Surveying elevation of roads in flooded areas;

- Set up and calibrate hydraulic models, detailed flooding downstream of the Hanh Stream dam;
- Mapping of flood downstream of Hanh Stream reservoir with frequency flood discharge: design, test, dam break corresponding to scenarios the operation of reservoir;

- Prepare plans for emergency response;

- Recommend and propose solutions to minimize the damage in emergency cases.

Fig. 3 will illustrate the process of solving these problems.

Below, the work of hydrological, hydraulic calculation of flooding of narrow coastal plain, the downstream of Hanh Stream reservoir, which located on the coastal of Cam Ranh Bay region, Khanh Hoa Province, Vietnam will be presented.

\section{Calculation Results and Discussion}

Based on these guidelines [4-6], we build models: calculating scenarios, simulating flood, andmapping of flood, etc. The main results [7] are presented as follows:

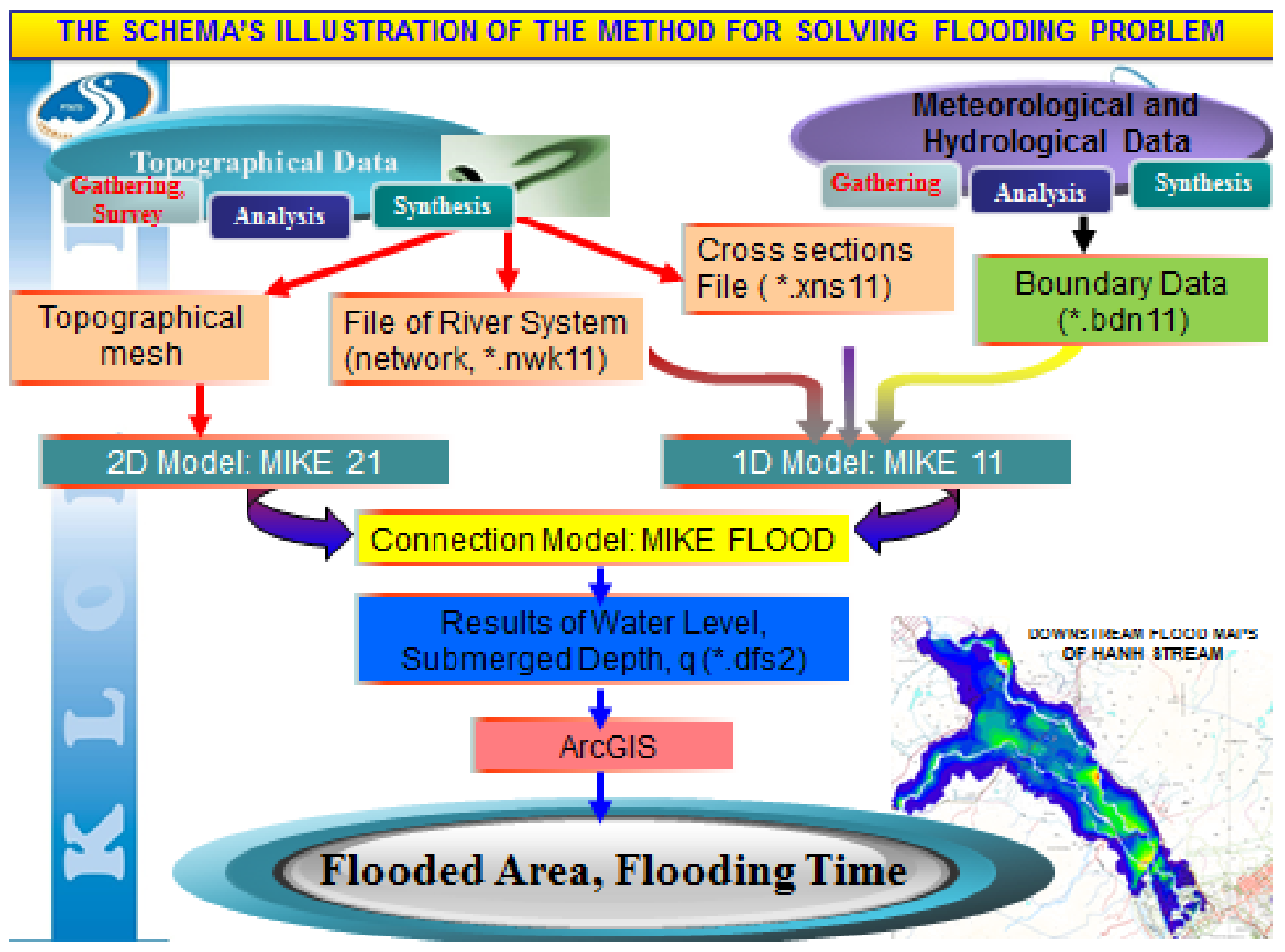


Fig. 3 The illustrating schema for method of solving flooding problem in Hanh Stream reservoir downstream.

\subsection{Selecting Representing Value for Calculating Raining Frequency}

Cam Ranh station's precipitation data from 1977 to 2013 facilitate for calculating the frequency of precipitation across the basin. From the measured data sequences of day periods, the deputies values of the largest daily rainfall total, the largest 3 days rainfall total or 5 consecutive days in a year of the flood period are determined (see Table 1).

\subsection{Selecting Result of Flooding Rains in the Design} Frequency

Using the flooding zooming factor in Cam Ranh station to zoom in or zoom out the flooding rains of entire Hanh Stream basin that based in the design frequency scenarios is appropriate.
After selecting the delegate rains that caused floods, we obtain a flow zooming factor at Cam Ranh station (see Table 2):

$$
\mathrm{KP}_{\text {Cam Ranh }}=\mathrm{X}_{\text {design }} / \mathrm{X}_{\max \text { Cam Ranh }}
$$

Select the largest rain day date 15 of Sep. 2012, the largest 3-day rain from 14 of Nov.-11 of Nov. 2012, the largest 5-day rain from 13 of Nov.-11 of Nov. 2012 to zoom to floods corresponding to the frequencies.

$\Rightarrow$ The large calculation zoom factor $\mathrm{Kp}$ and the selection of such rains for zooming are due to the big rain value at the moment, rainfall evenly distributed during the day;

$=>$ So using rainfall-runoff model-MIKE NAM for calculating flow discharges for Cam Ranh station will get a flood peak similar to design and inspection flood peak over spillway.

Table 1 The results of calculated frequency of largest precipitation: daily, 3 and 5 days;

\begin{tabular}{lllll}
\hline \multirow{2}{*}{$\begin{array}{c}\text { Ordinal } \\
\text { Number }\end{array}$} & P\% & \multicolumn{3}{c}{ Cam Ranh Rainfall Station } \\
\cline { 3 - 5 } & & The largest daily precipitation total & The largest 3 days precipitation total & $\begin{array}{l}\text { The largest 5 days precipitation } \\
\text { total }\end{array}$ \\
\hline & XTB & 148.71 & 220.32 & 254.24 \\
& CV & 0.35 & 0.39 & 0.38 \\
& CS & 1.8 & 1.39 & 1.48 \\
1 & 0.01 & 565.71 & 822.69 & 952.84 \\
2 & 0.10 & 446.21 & 661.83 & 763.10 \\
3 & 0.20 & 410.94 & 613.47 & 706.31 \\
4 & 0.33 & 385.66 & 578.48 & 665.31 \\
5 & 0.50 & 364.80 & 549.39 & 631.29 \\
6 & 1.00 & 330.23 & 500.67 & 574.44 \\
\hline
\end{tabular}

Table 2 The zooming factor values of largest daily rainfall with frequencies of the station Cam Ranh.

\begin{tabular}{|c|c|c|c|c|c|}
\hline Station & Frequency & $X_{t d}$ & $\mathrm{X}_{\mathrm{tk}}$ & Coefficient $\mathrm{K}_{\mathrm{p}}$ & Deputies Year \\
\hline \multirow{10}{*}{ Cam Ranh } & \multicolumn{5}{|c|}{ The largest daily precipitation total } \\
\hline & $0.10 \%$ & 120.7 & 446.21 & 3.70 & $15 / 09 / 2012$ \\
\hline & $0.20 \%$ & 120.7 & 410.94 & 3.40 & $15 / 09 / 2012$ \\
\hline & $1.00 \%$ & 120.7 & 330.23 & 2.74 & $15 / 09 / 2012$ \\
\hline & \multicolumn{5}{|c|}{ The largest 3 day precipitation total } \\
\hline & $0.10 \%$ & 233.8 & 661.83 & 2.83 & $14 / 11 / 2012$ \\
\hline & $0.20 \%$ & 233.8 & 613.47 & 2.62 & $14 / 11 / 2012$ \\
\hline & $1.00 \%$ & 233.8 & 500.67 & 2.14 & $14 / 11 / 2012$ \\
\hline & \multicolumn{5}{|c|}{ The largest 5 day precipitation total } \\
\hline & $0.10 \%$ & 237.2 & 763.1 & 3.22 & $13 / 11 / 2012$ \\
\hline
\end{tabular}




\begin{tabular}{lllll}
\hline $0.20 \%$ & 237.2 & 706.31 & 2.98 & $13 / 11 / 2012$ \\
$1.00 \%$ & 237.2 & 574.44 & 2.42 & $13 / 11 / 2012$ \\
\hline
\end{tabular}

Table 3 The MIKE NAM model parameters.

\begin{tabular}{llll}
\hline Parameters & Values & Parameters & Values \\
\hline $\mathrm{U}_{\max }$ & 18.2 & TOF & 0.168 \\
$\mathrm{~L}_{\max }$ & 245 & TIF & 0.0576 \\
CQOF & 0.86 & TG & 0.68 \\
CKIF & 1,000 & CKBF & 1,260 \\
CK1,2 & 11.2 & & \\
\hline
\end{tabular}

\subsection{MIKE NAM Model}

MIKE NAM model has a total of 19 parameters, with Vietnamese conditions, the parameters in tank snow (4 parameters) should be skipped (see Tables 3 and 4). Actually calculations show that only 5 parameters can influence the flow formation process and in fact, we may skip a few parameters that have no significant impact on the flow (the parameters of the irrigation Module, the parameters of groundwater extraction module etc.).

The computed performance of the flooding rains with the designed frequency is required for calculating the flood in the Hanh Stream reservoir basin in order to serve for design and planning purposes.

On the other hand, there are not any data of flow to downstream of Hanh Stream reservoir, hence the calculating of rainwater to flow by applying rainfall runoff model was required. Based on measurements of water levels in Hanh Stream reservoir from 2003 to June 2014, we were using a combination of one-dimensional hydrodynamic model MIKE 11HD and rainfall runoff model MIKE NAM flow to compare the results between the calculating reservoir water level and the observed water level since that used the most optimal parameters to calculate the flow for serving the input boundary of hydraulic model 1D and 2D.

The collected meteorological data serving to the hydraulic model are hourly data series of typical torrential rains occurred in the basin as torrential rains history 2012 in Cam Ranh station.

The recorded data of water level in the operation books of Hanh Stream reservoir are supplied by to Irrigation Management and Operation Company of Nam Khanh Hoa.

Flow in the river is depending on the tidal water level in Cam Ranh and discharge flow at the boundary of Hanh Stream and Ta Ruc. The flooding flow on the river is followed the regime of unstable flow, free surface flow and slow change in the natural bed are described by systems of partial differential equations Saint-Vernant as follows:

$$
\begin{gathered}
\frac{\partial \mathrm{Q}}{\partial \mathrm{x}}+\frac{\partial \mathrm{A}}{\partial \mathrm{t}}=\mathrm{q} \\
\frac{\partial \mathrm{Q}}{\partial \mathrm{t}}+\frac{\partial}{\partial \mathrm{x}}\left(\alpha \frac{\mathrm{Q}^{2}}{\mathrm{~A}}\right)+\mathrm{gA} \frac{\partial \mathrm{h}}{\partial \mathrm{x}}+\frac{\mathrm{gQ}|\mathrm{Q}|}{\mathrm{C}^{2} \mathrm{AR}}=0
\end{gathered}
$$

where,

$\mathrm{Q}$ is the flow rate;

A is wet section area;

$\mathrm{q}$ is the flow joined the middle area;

$\mathrm{h}$ is the depth of water;

$\mathrm{C}$ is the Chezy coefficient;

$\mathrm{R}$ is the hydraulic radius;

$\mathrm{g}$ is the gravitational acceleration.

Calculation of the Actual Flow by the Hydraulics Method

Because there are not any collected data about stream flows to the reservoir and we have only measured water level data in Hanh Stream reservoir from 2003 to June 2014 and Cam Ranh station rainfall data from 1977 to 2013 therefore it is incalculable NASH coefficient between calculated flow and measured flow from MIKE NAM model. So we had 
to use the measured water level data and the parameters of the reservoir in order to calculate the flow to the Hanh Stream reservoir following the formula:

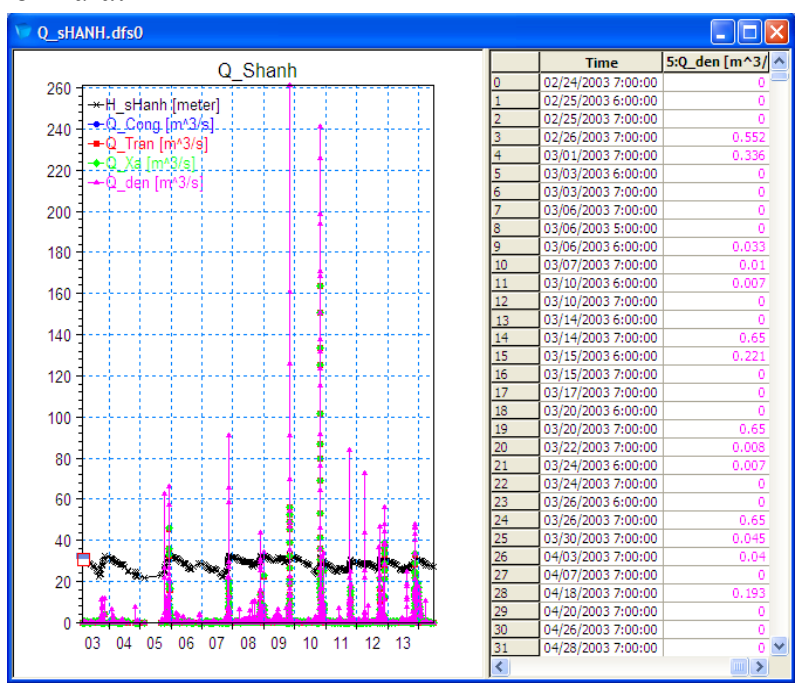

Fig. 4 Coming flow calculated from the measured water level of the Hanh Stream reservoir.

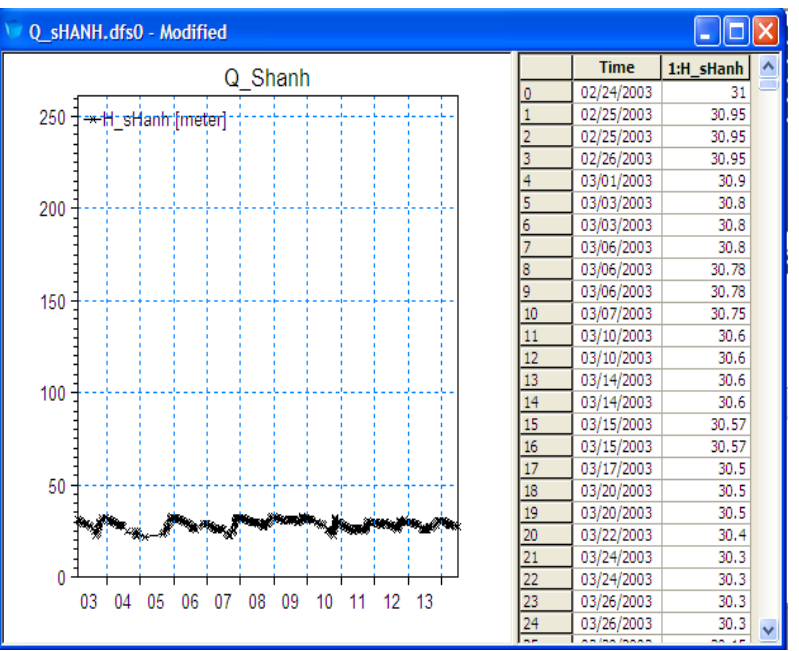

Fig. 5 The measured water level of the Hanh Stream reservoir.

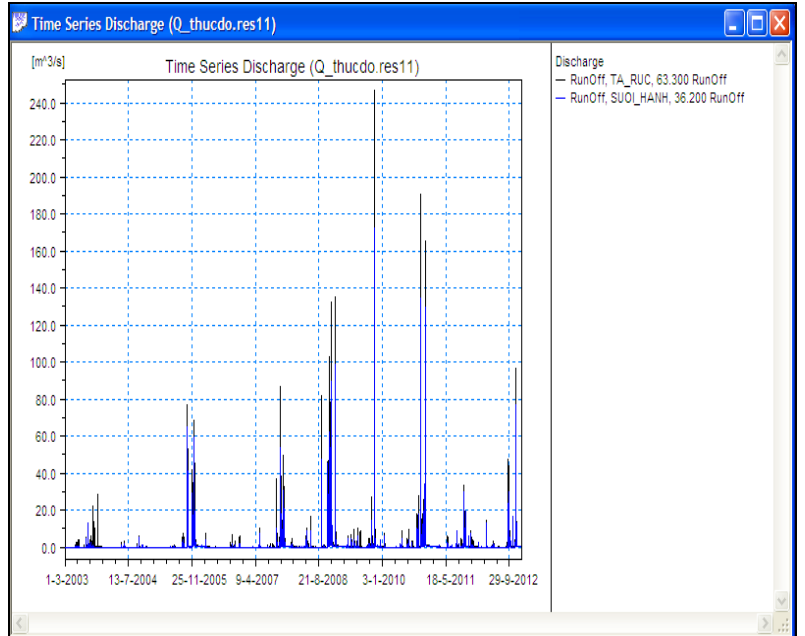

Fig. 6 Calculating results of the coming actual flow by the hydraulics method.

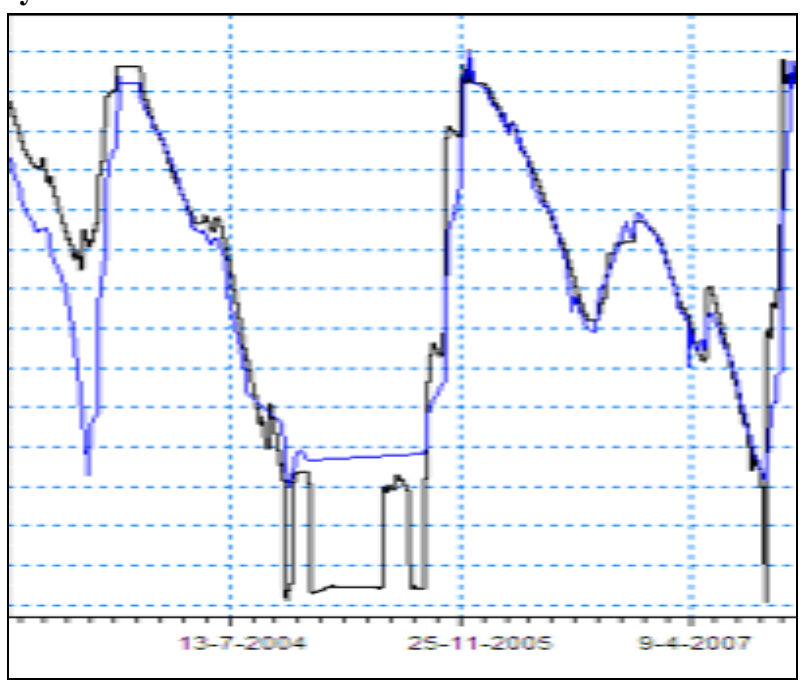

Fig. 7 Results of calibration in MIKE 11 HD model.

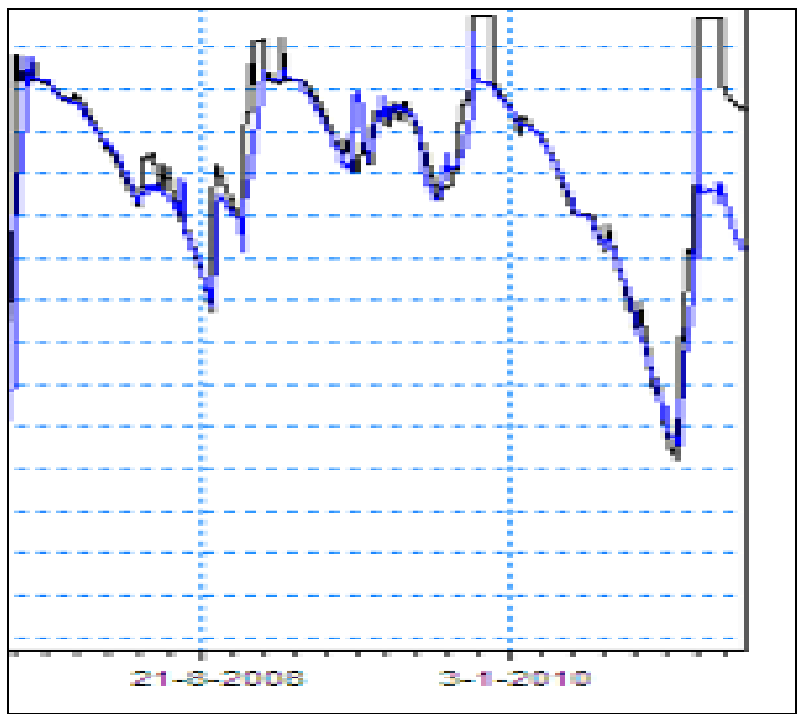

Fig. 8 The test results in MIKE 11 HD model. 


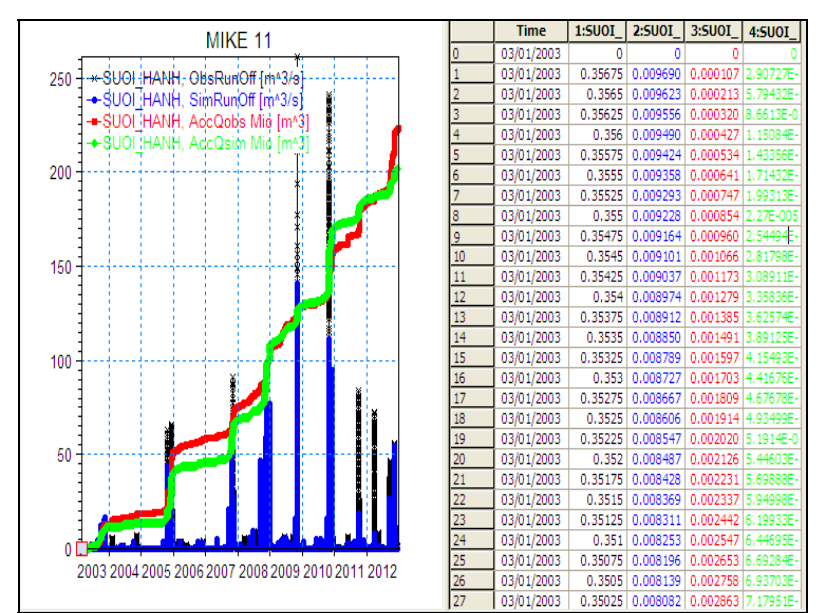

Fig. 9 Comparing results of coming flow calculated from measured water levels and flow calculations in MIKE NAM.

$$
Q=m * B \sqrt{2 g H^{3}}
$$

Determining overflow discharge factor when opening of all the sluice is $m=0.34$. This calculated coefficient was mentioned to transverse contraction and water column approaching velocities.

\subsection{Flood Model}

- In this study, the model MIKE 11 of Danish Hydraulic Institute was used to calculate the hydraulic regime on Hanh stream system;

- Hydraulic one-dimensional model of two major tributaries: the Hanh River and Ta Ruc River had been set up.

From documents:

- Topographic bed surveying (survey along and horizontal) Hanh Stream, Ta RucStream;

- Map 1/10,000 and 1/2,000 Hanh Stream basin;

- The upstream marginal is the flow behind 2 reservoirs Hanh Stream, Ta Ruc Streamwas zooming from the flood in 2012;

- Marginal downstream is the Cam Ranh $\mathrm{H}$ tide station;

- Additional rainfall in the basin;

- MIKE FLOOD allows to connect 2 models MIKE 11 and MIKE 21 in the calculation process, increasing grid step of the model (i.e. reducing the computation time) but still simulated the flow in the bed or on field surface and on flood cells as well as simulated hydrological, hydraulic processes across works systems;

- Calibration of roughness, time, calculation time step is performed by gradually method. (n) coefficient was built on the the map 1:10,000 ranged from 0.022 to 0.035 ;

- Test results of the model with measured data in 2010 when the Hanh Stream reservoir flow discharge $\mathrm{Q}_{\max }=234 \mathrm{~m}^{3} / \mathrm{s}$ indicates that the water level simulation model is the quite appropriate.

With a completed, new, detailed topographic survey data are included in the model and calibration verification with the floods of 2010 .

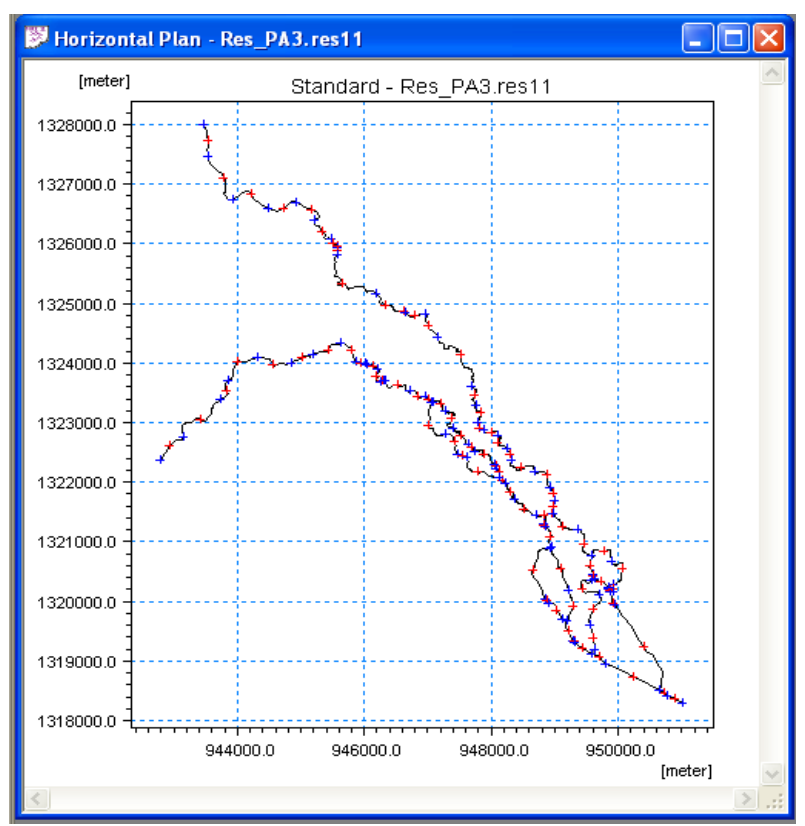

Fig. 10 1D hydraulic network. 

Reservoir Flood Discharge in Rainy and Extreme Flood Conditions

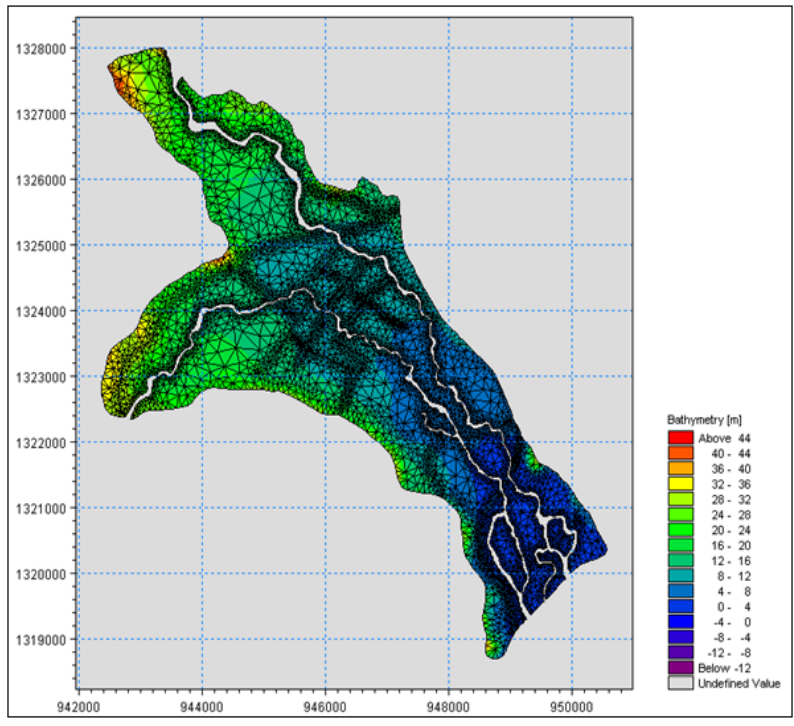

Fig. 11 River network diagrams and computing meshs.

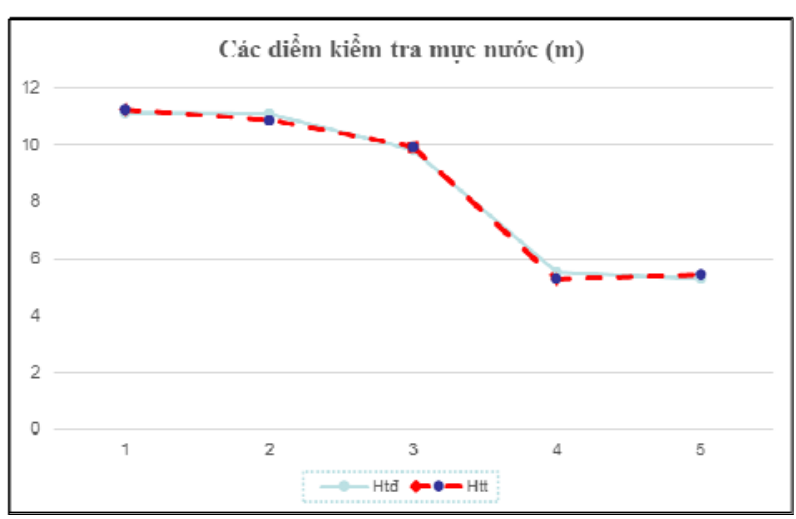

Fig. 12 Test results of water values.

Therefore it can be concluded that input hydraulic model MIKE Flood has built enough confidence to apply, calculate, simulate hydraulic factors on the downstream network of Hanh Stream reservoir, better support for researching flood.

\subsection{Hydraulic Calculation Results}

\subsubsection{Case $\mathrm{P}=0.1 \%$}

- There are 5 points in the checkpoint with flood depth greater than $2 \mathrm{~m}$;

- There are 10 points in the checkpoint with flood depth greater than $1 \mathrm{~m}$;

- There are two points in the checkpoint with submerged time greater than 20 hours;

- There are 16 points in the checkpoint with submerged time greater than 10 hours.

3.5.2 Case $\mathrm{P}=0.2 \%$
- There are 2 points in the checkpoint with flood depth greater than $2 \mathrm{~m}$;

- There are 10 points in the checkpoint with flood depth greater than $1 \mathrm{~m}$;

- There are two points in the checkpoint with submerged time greater than 20 hours;

- There are 14 points in the checkpoint with submerged time greater than 10 hours.

3.5.3 Case $\mathrm{P}=1 \%$

- There are 7 points in the checkpoint with flood

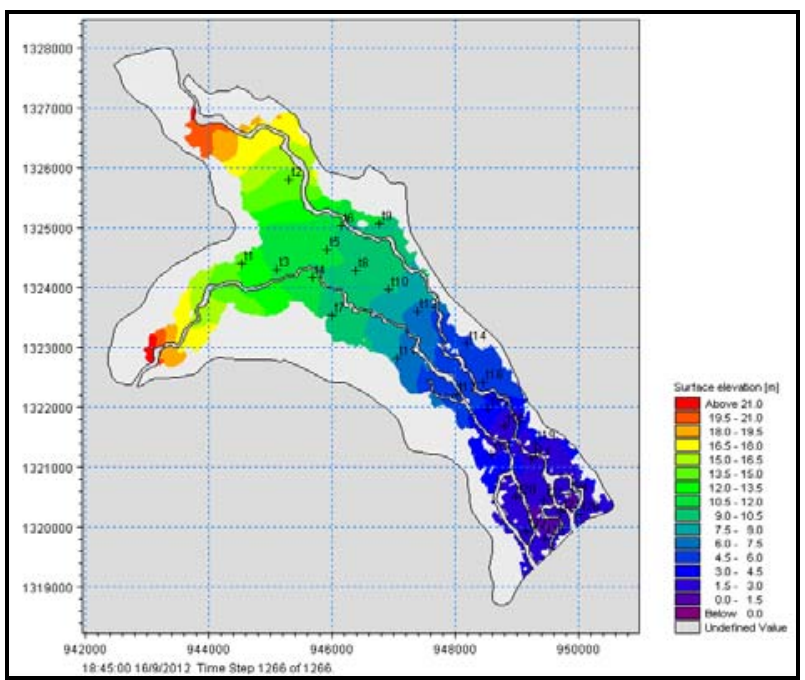

Fig. 13 Calculation results of water levels, case $P=0.1 \%$, $\mathrm{Q}=614 \mathrm{~m}^{3} / \mathrm{s}$.

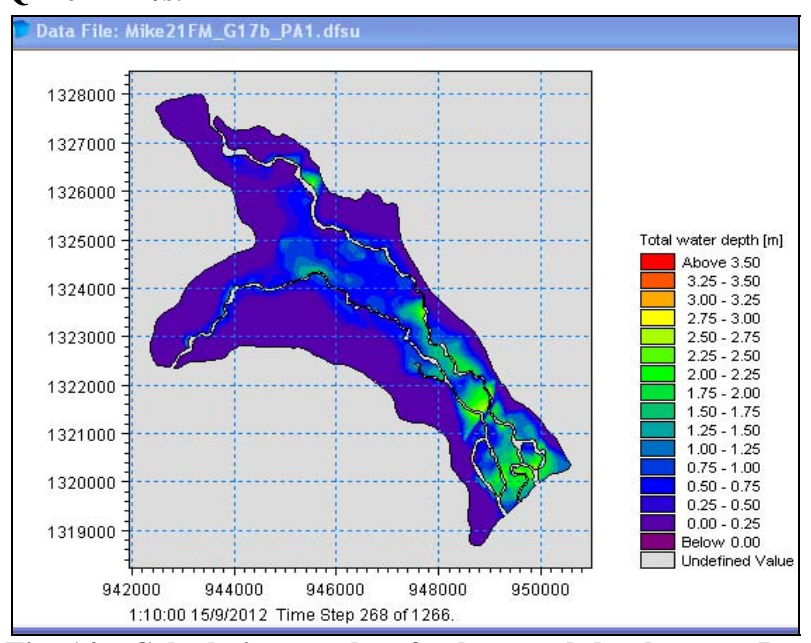

Fig. 14 Calculation results of submerged depths, case $\mathbf{P}=$ $0.1 \%, Q=614 \mathrm{~m}^{3} / \mathrm{s}$. 

Reservoir Flood Discharge in Rainy and Extreme Flood Conditions

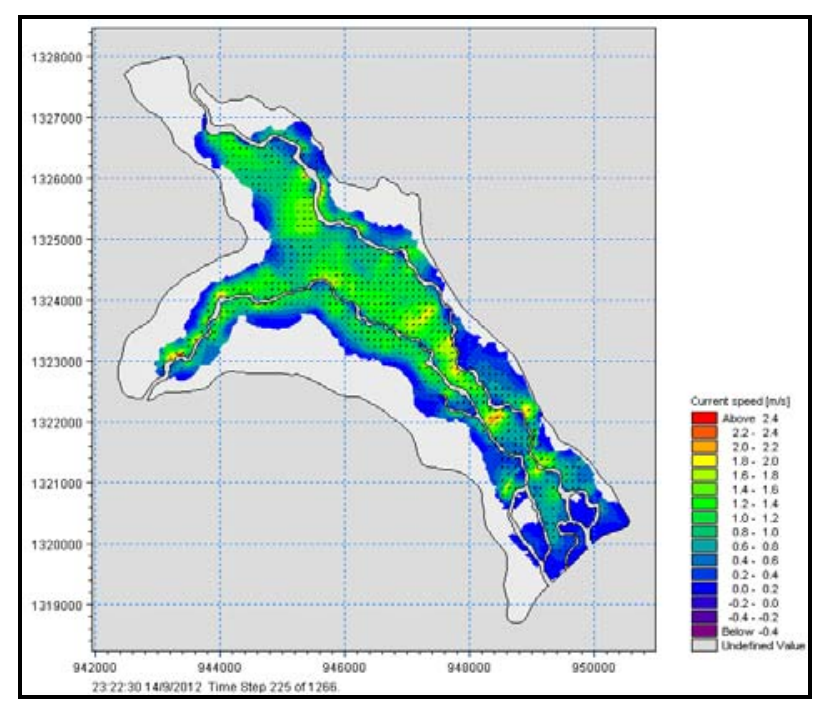

Fig. 15 Velocity distribution, case $P=0.1 \%, Q=614 \mathrm{~m}^{3} / \mathrm{s}$.

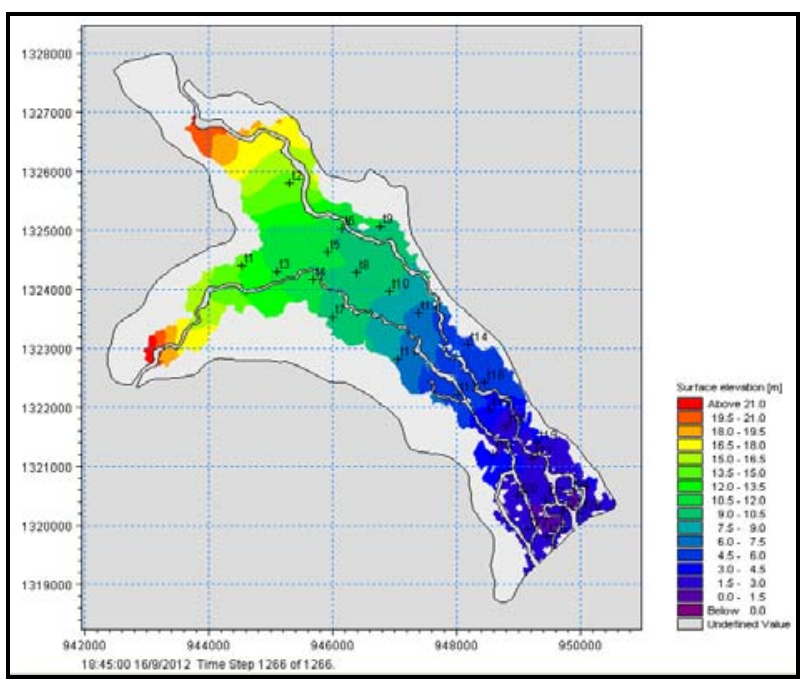

Fig. 16 Calculation results of water levels, case $P=0.2 \%$, $\mathrm{Q}=517 \mathrm{~m}^{3} / \mathrm{s}$.

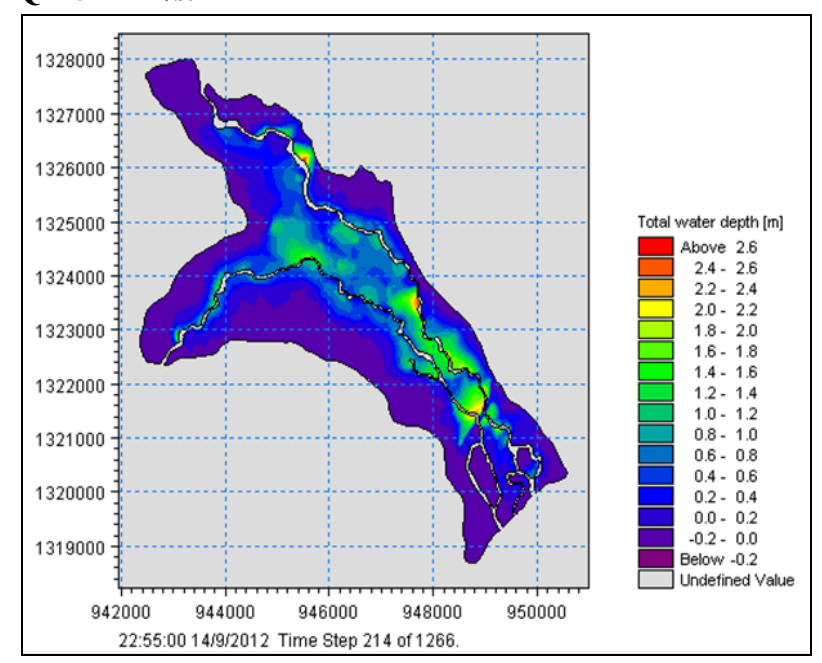

Fig. 17 Calculation results of submerged depths, case $\mathbf{P}=$ $0.2 \%, Q=517 \mathrm{~m}^{3} / \mathrm{s}$.

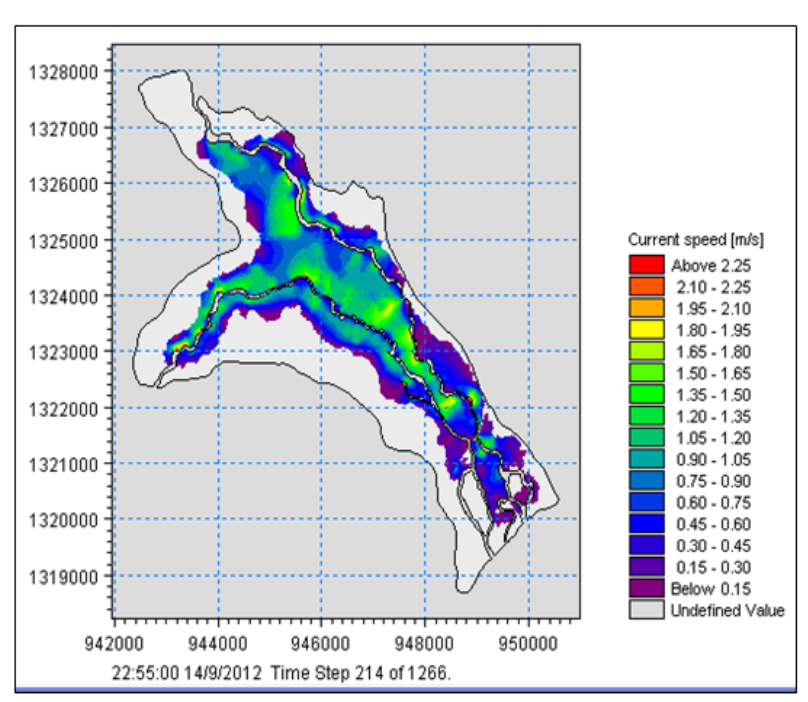

Fig. 18 Velocity distribution, case $P=0.2 \%, Q=517 \mathrm{~m}^{3} / \mathrm{s}$.

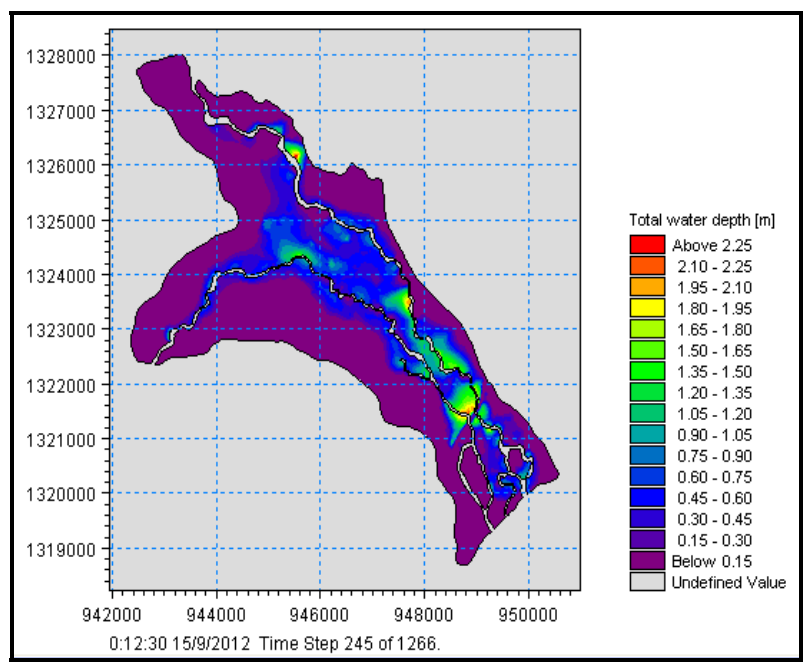

Fig. 19 Calculation results of submerged depths, case $\mathbf{P}=$ $1 \%, \mathrm{Q}=396 \mathrm{~m}^{3} / \mathrm{s}$.

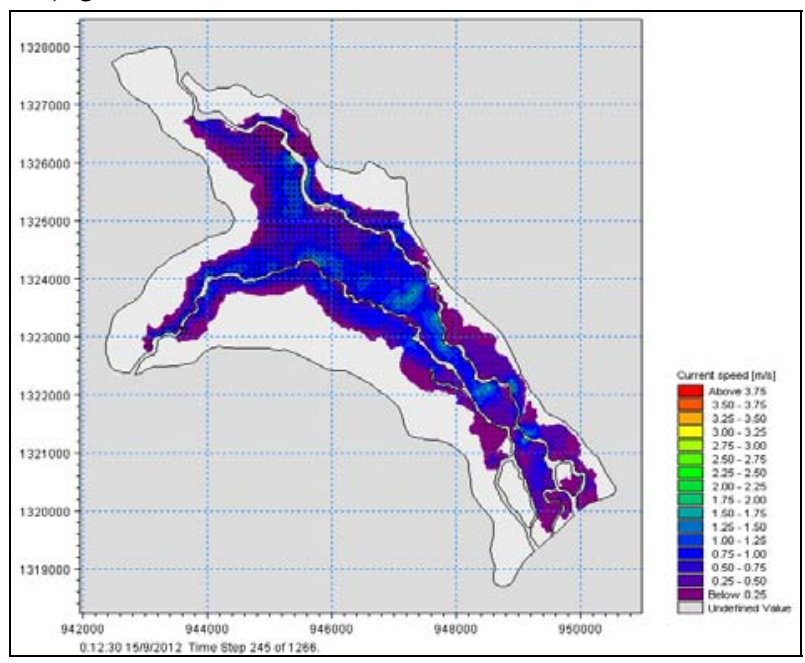

Fig. 20 Velocity distribution, case $P=1 \%, Q=396 \mathrm{~m}^{3} / \mathrm{s}$. 
depth greater than $1 \mathrm{~m}$;

- There are two points in the checkpoint with submerged time greater than 20 hours;

- There are 9 points in the checkpoint with submerged time greater than 10 hours.

Due to quite steep terrain of basin, the flow concentrates fast upon the occurrence of flood scenarios. The flooded time with large inundation depth usually lasts for a day. Upstream water level fluctuation is over $20 \mathrm{~m}$, the downstream water level is $1 \mathrm{~m}$ and smaller. Flooded sector takes over 2/3 study area (see Table 5). corresponding to the frequency of floods;

- The time of the flood that started to affect the lives and material wealth;

- Effect time of floods;

- Flood maps are considered an important tool for building evacuation maps, help significantly reduce the human and economic damages, so the work of disaster prevention and reduction will achieve high efficiency;

- Classes map;

- Boundaries: including national boundaries, the provincial boundary, district and communal boundaries;

\subsection{Flooding Maps}

Flooding maps will be basically shown:

- Level's largest flooding deep at a position

Table 4 Calculation results of flood flow according to different frequency values through MIKENAM model.

\begin{tabular}{lllllll}
\hline \multirow{2}{*}{ Frequencies } & \multicolumn{2}{c}{ The largest daily precipitation total } & \multicolumn{2}{c}{ The largest 5 day precipitation total } & \multicolumn{2}{c}{ The largest 5 day precipitation total } \\
\cline { 2 - 7 } & $\mathrm{Q}_{\text {Hanh Stream }}\left(\mathrm{m}^{3} / \mathrm{s}\right)$ & $\mathrm{Q}_{\text {Ta Ruc }}\left(\mathrm{m}^{3} / \mathrm{s}\right)$ & $\mathrm{Q}_{\text {Hanh Stream }}\left(\mathrm{m}^{3} / \mathrm{s}\right)$ & $\mathrm{Q}_{\text {Ta Ruc }}\left(\mathrm{m}^{3} / \mathrm{s}\right)$ & $\mathrm{Q}_{\text {Hanh Stream }}\left(\mathrm{m}^{3} / \mathrm{s}\right)$ & $\mathrm{Q}_{\text {Ta Ruc }}\left(\mathrm{m}^{3} / \mathrm{s}\right)$ \\
\hline $0.10 \%$ & 637.04 & $1,113.94$ & 549.48 & 908.37 & 635.83 & $1,138.8$ \\
$0.20 \%$ & 543.71 & 950.75 & 447.15 & 781.89 & 554.23 & 996.39 \\
$1.00 \%$ & 340.12 & 594.74 & 282.33 & 493.69 & 377.69 & 660.43 \\
\hline
\end{tabular}

Table 5 Calculation Results of flooded time and Submerged area.

\begin{tabular}{lllll}
\hline Flooding scenario & Flooded time (hours) & $\begin{array}{l}\text { The water level in upstream of The water level in } \\
\text { flood area } \\
(\mathrm{m})\end{array}$ & $\begin{array}{l}\text { downstream of flood area } \\
(\mathrm{m})\end{array}$ & $\begin{array}{l}\text { Flooded area } \\
\text { (ha) }\end{array}$ \\
\hline $\mathrm{P}=0.1 \%$ & 24 & 21 & 1.2 & $1,167.37$ \\
$\mathrm{P}=0.2 \%$ & 24 & 21 & 1.3 & $1,094.84$ \\
$\mathrm{P}=1 \%$ & 20 & 21 & 1.5 & 895.09 \\
$\mathrm{P}=0.2 \%+$ Vỡ đập & 22 & 23.5 & 0.9 & $1,234.89$ \\
\hline
\end{tabular}

Table 6 Evacuation plans in case of heavy flooding.

\begin{tabular}{|c|c|c|c|c|}
\hline Ordinal & $\begin{array}{l}\text { Administrative units } \\
\text { affected by flooding }\end{array}$ & $\begin{array}{l}\text { Number of } \\
\text { households need to } \\
\text { evacuate }\end{array}$ & $\begin{array}{l}\text { The number of } \\
\text { people need to } \\
\text { evacuate }\end{array}$ & Expected evacuation area \\
\hline I & Cam Ranh City & & & \\
\hline 1 & Cam Phuoc Dong commune & 65 & 250 & $\begin{array}{l}\text { Two floors house on consolidation, at hamlet } \\
\text { Giai Phong }\end{array}$ \\
\hline 2 & Ba Ngoi Town & 24 & 85 & $\begin{array}{l}\text { Two floors house on consolidation, at hamlet } \\
\text { Giai Phong, besides of Doc San mountain }\end{array}$ \\
\hline II & Cam Lam District & & & \\
\hline 1 & Cam Phuoc Tay commune & 108 & 420 & $\begin{array}{l}\text { Church, Elementary School, Nursery School, } \\
\text { Two floors house on consolidation, at hamletVăn } \\
\text { Thủy 1, besides of Nhon mountain }\end{array}$ \\
\hline
\end{tabular}

- Transport: including highways, railways;

- Rivers: including river systems, lakes;

- Landmarks: including name province, district and national name;

- The class map is edited properly by the ratio map 1: 10,000 . 


\section{Conclusions}

By studying the occurrence of extreme flood case (considered to climate change conditions), the calculated results showed that the whole area right $\mathrm{Ta}$ Ruc and left of the Hanh Stream are completely flooded. Although downstream of Hanh Stream lies in the narrow coastal plain, with large topographical slope, the ability to focus flow quickly, but it is not so large basin and has been separated by the railway system and Highway 1. Therefore the inundation flood only primarily affected area nearby downstream of the dam. The more out of the sea, the less flooded influence. When large flooding, in estuaries and Cam Ranh Bay, the water level increases slightly so that boats still travel normally. However, the residential area near the dam still heavily flooded and we should have evacuation plans in case of emergency. Table 6 is presented more details on the amount of people and safe places to evacuate people in the flooding affected areas.

Due to the critical nature concerning human safety and property, the determination of time of large flood is extremely important to make the announcement of dangerous to people in the downstream. The implementation time of warning before flood discharge through the spillway longer than time of alert of incidents then we will have time for doing all requirement things. Therefore, we need to try hard to minimize the possibility of dam break phenomenon,

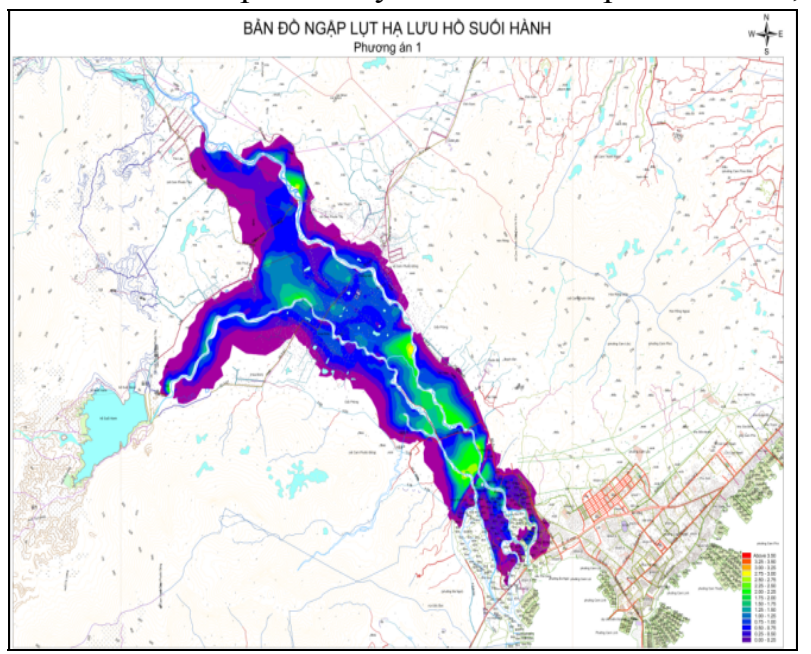

Fig. 21 Flood maps corresponding frequency $P=0.1 \%$.

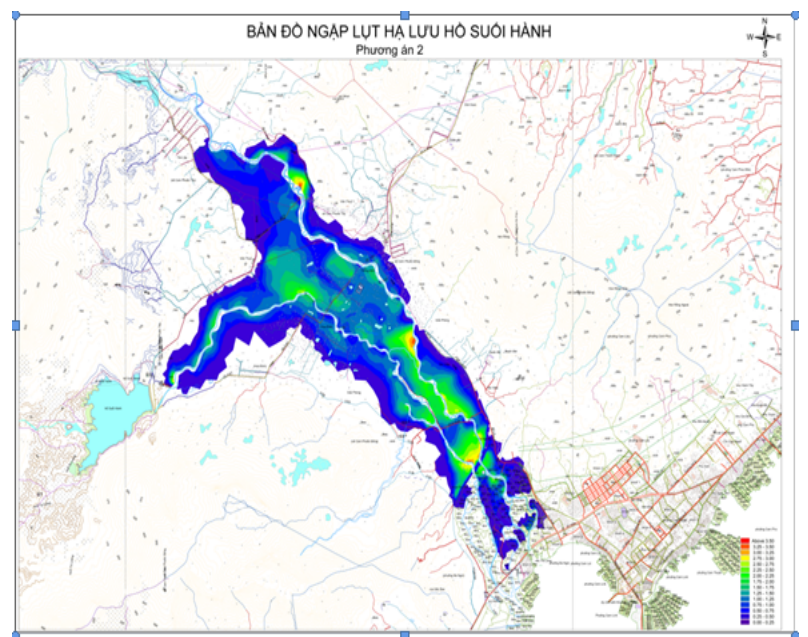

Fig. 22 Flood maps corresponding frequency $P=0.2 \%$.

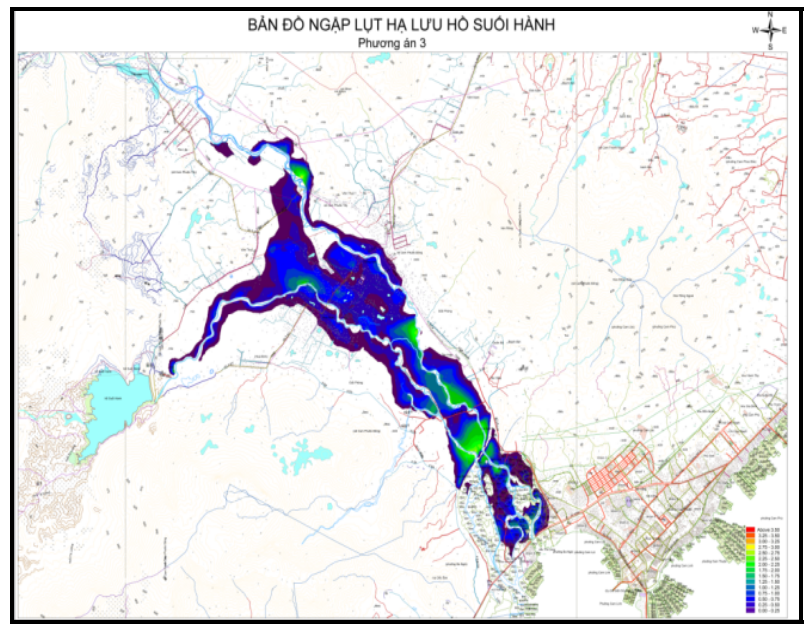

Fig. 23 Flood maps corresponding frequency $P=1 \%$.

abnormal flood discharge or at least slowing down the process to people downstream of the dam could be informed and evacuated. These things could be done when we warn early and have good emergency response plans.

To achieve these purposes, when incidents or large flood to the reservoir, the local managers are recommended to immediately perform the following tasks:

(1) In case of occurrenceof unusually large flood

- Based on the information on hydrology, flood prediction to adjust operational procedures, determine the discharge flow through the overflow and flooding capability at downstream for resolution of alert and 
necessary rescue;

- Continuing to check the situation of the construction items, detection of errors that may occur to timely handling.

(2) In case of occurrence of dangerous situations

Together with the initial rescue operation, planning to troubleshoot. First performed the motto 4 in place, full mobilization of locally available forces to overcome. Having expected plan to mobilize rescue forces appropriate with characteristics of the incidents, the field conditions, the accessibility the field etc. (to mobilize forces manually or motorized equipment or both 2 types). At the same time notice to these forces for ready preparing.

In addition to the evacuation of people and assets to safe places, it should be noted the following issues:

- The field of shrimp farming adjacent to Cam Ranh bay is capable heavy inundation when there is occurrence of extreme flood. The fisheries protection plan is needed during the rainy season to reduce damage;

- Flood maps indicated that the location Elementary School, Kindergarten School and the Church would be pretty safe place, when there occurred extreme floods or dam break;

- Based on the calculation results, Key Laboratory of Hydraulics, River and Coastal Engineering proposed: "Planning and preparing response plans for emergencies" to the responsible agency of the Khanh Hoa province.

\section{Acknowledgments}

The study is conducted in the framework of the project "Repair and upgraded to ensure safety of Hanh Stream reservoir of Khanh Hoa province". The Key Laboratory of Hydraulics, River and Coastal Engineering is the consultant. In the process of performing the task, we have the supports of the Water Resource Directorate, Provincial DARD of
Khanh Hoa and there is close cooperation with the agency: Co. Ltd Irrigation Management and Operation Company of Nam Khanh Hoa and Steering Committee of Prevention, flood control, search and rescue of Khanh Hoa province, the Management Board Hanh Stream dam. We would like to thank the cooperation and assistance of organizations and individuals to the Key Laboratory of Hydraulics, River and Coastal Engineering and the research team.

\section{References}

[1] Le Bac Huynh. 2005. "Research, Development Methodology and Technology for Forecasting Hydrological Term." Hanoi: Water Resources Management Department.

[2] Department of Hydrometeorology and Climate Change. 2012. "Extreme Weather due to Climate Change." Online, Accessed on June 23, 2015. http://stnmt.binhduong.gov.vn/3cms/thoi-tiet-cuc-doando-bien-doi-khi-hau.htm.

[3] IMHEN và UNDP. 2015. "Summary Report Serves Policy Makers." In a Special Report of the Vietnam on the Management Disaster Risks and Extreme Events in order to Promote Adaptation to Climate Change. Hanoi: Publishing House for Environmental Resources and Map.

[4] Danish Hydraulic Institute (DHI). 2011. Mike11 User Manual.

[5] Danish Hydraulic Institute (DHI). 2011. Mike 21 Reference Manual.

[6] Nguyen Ngoc Nam, Le Van Nghi, Bui Thi Ngan et al. 2014. Prepare Plans for Prevention from Floods in Downstream Areas of Hanh Stream Reservoir, Khanh Hoa Province. Technical Report of Key Laboratory of Hydraulics River and Coastal Engineering.

[7] UNESCO. 2009. "IWRM Guidelines at River Basin Level-Part 2-2: The Guidelines for Flood Management." United Nations Educational, Scientific and Cultural Organization, International Hydrological Programme of UNESCO, World Water Assessment Programme, NARBO. 